\title{
Potenciál aplikace přírodě blízkých opatření pro zadržení vody v krajině a zlepšení ekologického stavu vodních útvarů
}

\author{
MIRIAM DZURÁKOVÁ, KAMILA ZÁRUBOVÁ, JANA UHROVÁ, MILOŠ ROZKOŠNÝ, LUKÁŠ SMELÍK, \\ DENISA NĚMEJCOVÁ, SVĚTLANA ZAHRÁDKOVÁ, PAVLA ŠTĚPÁNKOVÁ, JAROMÍR MACKŮ
}

Klíčová slova: sucho - retence vody - přírodě blízká opatření - opatření v ploše povodí -

malé vodní nádrže - opatření na tocích - biologické složky

\section{SOUHRN}

V rámci prací na sestavení návrhu koncepce ochrany před následky sucha na území České republiky byla provedena analýza a hodnocení potenciálu př́rodě blízkých opatření pro zadržení vody v krajině. Vyhodnoceny byly vybrané typy opatření v ploše povodí (na zemědělské i lesní půdě), malé vodní nádrže a opatření na tocích, včetně jejich potenciálního vlivu na biologickou složku ekologického stavu. Výsledkem jsou doporučení vhodných typů opatření pro zvýšení retence vody v krajině, která zároveň přispějí ke zlepšení ekologického stavu vodních útvarů nebo jej alespoň nezhorší. Účinnost navrhovaných opatrení byla ověřována v pilotním povodí Husího potoka, a to modelováním v programu HEC-HMS.

\section{ÚVOD}

Řešení vycházelo z hodnocení typů opatření, které byly definovány v projektu Strategie ochrany pred negativními dopady povodní a erozními jevy prírodě blízkými opatřeními v České republice a které jsou publikovány na portálu www.vodavkrajine.cz. Jednalo se o návrhy komplexních a propojených systémů protipovodňových a protierozních opatření v ploše povodí na zemědělské půdě (organizační, agrotechnická a biotechnická), návrhy malých vodních nádrží, opatření na lesní půdě a opatření na vodních tocích a v nivách.

Pro účely posouzení opatření z hlediska zvýšení retence vody $v$ krajině byly do souboru těchto typů opatření přidány $\mathrm{k}$ hodnocení i mokřadní biotopy. Vhodnost použití malých vodních nádrží (MVN) byla posuzována samostatně pro každý typ MVN podle [1]. Rovněž revitalizace toků byly hodnoceny podrobně, z pohledu jednotlivých návrhových prvků systému.

\section{OPATŘENÍ V PLOŠE POVODÍ NA ZEMĚDĚLSKÉ PŮDĚ}

Vhodně navržená ochranná opatření v krajině plní vždy řadu funkcí (protierozní, protipovodňovou, ochranu pred suchem, ale i ekologickou) zásadně podporujících ochranu krajinných systémů a jejich obnovu v místech predchozího narušení způsobeného převážně za přispění lidské činnosti. Vhodně navržená protipovodňová a protierozní opatření mají i velice pozitivní vliv při ochraně před následky sucha, protože celková ochrana povodí sleduje tyto základní cíle: - co nejvíce podpořit vsakování vody do půdy;

- omezit soustředování odtoku do stružek, tzn. podpořit jeho rozptylování;

- zpomalovat a neškodně odvádět povrchový odtok tak, aby nenabyl unášecí síly schopné odnášet zeminu;

— prodloužit dobu retence vody v ploše povodí.

Omezení délky svahu, zkrácení dráhy odtoku, snížení rizika vzniku soustředěného povrchového odtoku a snížení jeho rychlosti i objemu spolu úzce souvisí a jedná se o hlavní funkce zejména liniových biotechnických opatření. Zvýšení vsaku vody do půdy a prodloužení doby infiltrace závisí jak na zpomalení povrchového odtoku, tak i na stavu půdy (nakypřená půda vodu lépe vsákne) a krajinném pokryvu. Narušení a degradace půdy hrozí zejména u půdy nechráněné krajinným pokryvem. Řešením proti tomu jsou opatření, jejichž součástí je zatravnění nebo jiná ochrana půdního povrchu. S ohledem na tyto účinky a další, uvedené podrobněji ve zprávě [2], jsou vhodnými krajinnými prvky, podporujícími udržení vody v krajině, právě zasakovací prvky. Ty splňují hlavní aspekty pro zmírnění účinků sucha - podpora infiltrace a prodloužení doby vsaku i zpomalení povrchového odtoku. Jedná se zejména o zasakovací př́kopy a průlehy, hrázky doplněné průlehy, přehrážky v údolnicích, zasakovací pásy apod. Tyto prvky je vhodné doplnit o travnatý pás s doprovodnou zelení, čímž se zvýší i jejich ekologická funkce a mohou být začleněny do územního systému ekologické stability (ÚSES).

Plošná opatření na zemědělské půdě (organizační, agrotechnická i na speciálních kulturách) jsou žádoucí opatření ve všech ohledech. Z hlediska řešení problematiky sucha je důležitý zejména jejich vliv na zpomalení povrchového odtoku a zvýšení infiltrace. Pro většinu plošných opatření na orné půdě platí, že zlepšují vodní režim v půdě a omezují důsledky eroze, což snižuje nežádoucí vnos erodovaných částic a na ně vázaných polutantů do vodního prostředí, což je $v$ důsledku pozitivní pro vodní organismy, a tedy i ekologický stav. Změnami ve využití a zpưsobu obdělávání zemědělských pozemků, ideálně doplněných biotechnickými prvky, Ize docílit zmírnění projevů sucha v krajině.

Při návrhu opatření podporujících zadržení vody v krajině je vhodné vycházet z historických map znázorňujících místa původního umístění krajinných prvků před kolektivizací, při které došlo k jejich rozorání (meze, polní cesty, mokřady atd.), a obnovovat je. 
Vhodnost $\mathbf{k}$ řešení problematiky sucha $\mathrm{z}$ hlediska

Typ opatření

Vodohospodářského

složky určující

ekologický stav/

potenciál (ES/EP)
Vlivu na fyzikálně-chemické a chemické parametry podporující biologické složky ES/EP

\section{Plošná opatření:}

\begin{tabular}{|c|c|c|c|}
\hline organizační & + & + & ++ \\
\hline agrotechnická & + & + & + \\
\hline speciální kultury & + & + & \\
\hline
\end{tabular}

\section{Biotechnická opatření:}

\begin{tabular}{|c|c|c|c|}
\hline zasakovací průleh/príkop & +++ & + & +++ \\
\hline svodný průleh/príkop & + & + & ++ \\
\hline zasakovací pásy & +++ & + & +++ \\
\hline stabilizace dráhy soustředěného odtoku & + & + & + \\
\hline hrázky & ++ & + & + \\
\hline meze & + & + & + \\
\hline terasy & 0 & - & 0 \\
\hline
\end{tabular}

\section{Malé vodní nádrže (podle}

ČSN 75 2410):

$$
\text { vodárenské }
$$

průmyslové

závlahové

energetické

kompenzační

aktivizační

retenční suché

retenční s nadržením

Čistící a usazovací

rybochovné

hospodářské

vyrovnávací

klauzury (lesní)

rekreační

krajinotvorné

rekultivační 
Vhodnost k řešení problematiky sucha z hlediska

Typ opatření

\section{Vodohospodářského \\ Vlivu na biologické \\ složky určující \\ ekologický stav/ \\ potenciál (ES/EP)}

\author{
Vlivu na fyzikálně-chemické \\ a chemické parametry \\ podporující biologické \\ složky ES/EP
}

\begin{tabular}{|c|c|c|c|}
\hline \multicolumn{4}{|l|}{ Opatření v lesích: } \\
\hline tvorba polyfunkčního lesa & + & 0 & + \\
\hline omezení smrku ve 3. a 4. LVS & + & + & + \\
\hline podrostní a násečný hospodářský způsob & + & 0 & + \\
\hline dodržování vhodných postupů při těžbě & + & 0 & 0 \\
\hline vhodná fragmentace lesa & + & 0 & 0 \\
\hline nízký tvar lesa (výmladkový, pařezina) & + & + & + \\
\hline $\begin{array}{l}\text { ochranné pásy lesa kolem vodárensky } \\
\text { významného toku }\end{array}$ & + & ++ & ++ \\
\hline
\end{tabular}

důsledná sanace potěžebních či jiných technologických narušení pưdy

0

\begin{tabular}{|c|c|c|c|}
\hline hrazení strží & + & +- & + \\
\hline hrazení bystřin & +- & +- & +- \\
\hline
\end{tabular}

Legenda: -, $0,+,++,+++-$ míra vhodnosti opatření od nevhodného po nejvhodnější

\section{MALÉ VODNÍ NÁDRŽE}

V rámci opatření typu malých vodních nádrží je hlavním pozitivem z pohledu zlepšení retence vody $v$ povodí akumulace vody a její možné využití v období sucha. S ohledem na funkce MVN, z nichž mnohé sice vodu akumulují, ale není možné ji v suchých obdobích využívat (např. z důvodu výskytu rybí obsádky), Ize za nejvhodnější označit retenční nádrže suché a s malým stálým nadržením, částečně i zásobní nádrže (zejména závlahové), které vytvářejí disponibilní zásoby vody pro využití v období sucha. Suché nádrže, zejména mimo vodní tok, na drahách soustředěného odtoku (DSO), kde netvoří migrační bariéru pro živočichy, zadržují vodu z přivalových srážek, čímž zpomalují povrchový

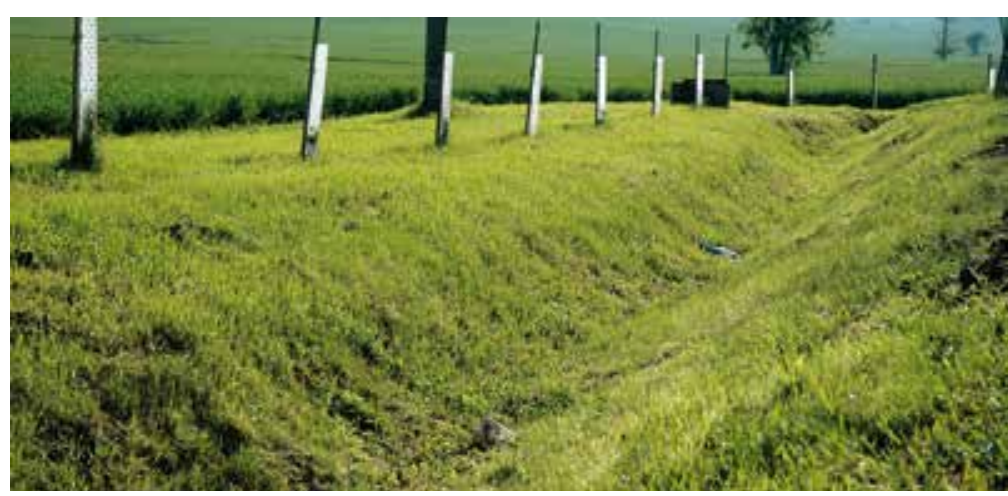

Obr. 1. Ukázka zatravněného př́ḱpou

Fig. 1. Example of a grassy ditch odtok. Retenční nádrže s malým stálým nadržením mohou v suchém období sloužit jako mokřady, čímž je podpořena retence vody v krajině. V období srážek se voda v retenčním prostoru akumuluje a obdobně jako u suchých nádrží může být později upouštěna. Tyto nádrže by se však neměly stávat útočištěm nepůvodních nebo invazivních druhů (např. ryba střevlička východní), popř. $\checkmark$ důsledku eutrofizace i zdrojem zhoršené kvality vodního prostředí v navazujících úsecích toků a zdrojem nadměrné biomasy fytoplanktonu. Návrh zátopy by měl zohlednit i tyto možné negativní dopady. Ideálně by měla být výška vodního sloupce těchto nádrží do 0,6 m. Závlahové nádrže mají hlavní výhodu $\checkmark$ akumulaci vody určené primárně pro závlahové systémy, z pohledu retence či zasakování vody jsou bezvýznamné, pro vodní ekosystémy negativní. Malé

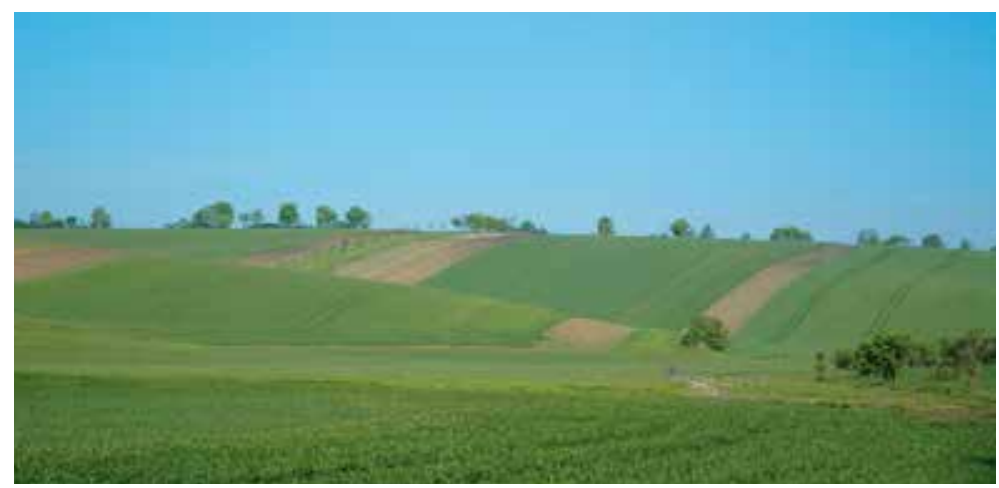

Obr. 2. Pásové střídání plodin v k. ú. Šardice

Fig. 2. Band rotation of crops, Šardice 
vodní nádrže jsou velmi diskutovaná opatření. Podle výsledků ze srážko-odtokových modelů Ize konstatovat, že dokáží zadržet poměrně velké množství vody $v$ povodí a následné nadlepšování průtoků v suchém období může mít pozitivní vliv na vodní toky pod nimi až několik dní. Vše však závisí na typu a ovladatelnosti spodních výpustí, zvoleném způsobu manipulace a manipulačním řádu. Často bývá v projektech nádrží uváděno, že nádrž bude v suchých obdobích sloužit k nadlepšování průtoků, po realizaci k tomu však nedochází (zejména u rybochovných či rekreačních nádrží, kde naopak v suchých obdobích téměř veškerou vodu zadržují a vypouští se pouze nezbytné stanovené minimum). Tuto problematiku by mohla alespoň částečně vyřešit např́klad vhodná změna legislativy a zejména její důsledné dodržování.

K identifikaci ploch zaniklých vodních prvků v krajině je možné využít certifikovanou mapu Současný stav historických rybníků na území České republiky [3], která je $\vee$ podobě interaktivní aplikace [4] dostupná v informačním systému HEIS VúV TGM, v. v. i. Pro rámcové posouzení využití ploch zaniklých vodních prvků $\vee$ krajině pro účely vodního hospodářství, realizaci vodních a mokřadních prvků (protipovodňová ochrana, opatření proti suchu apod.) Ize využít certifikovanou metodiku [5] zabývající se hodnocením ploch zaniklých rybníků z hlediska optimalizace jejich využití.

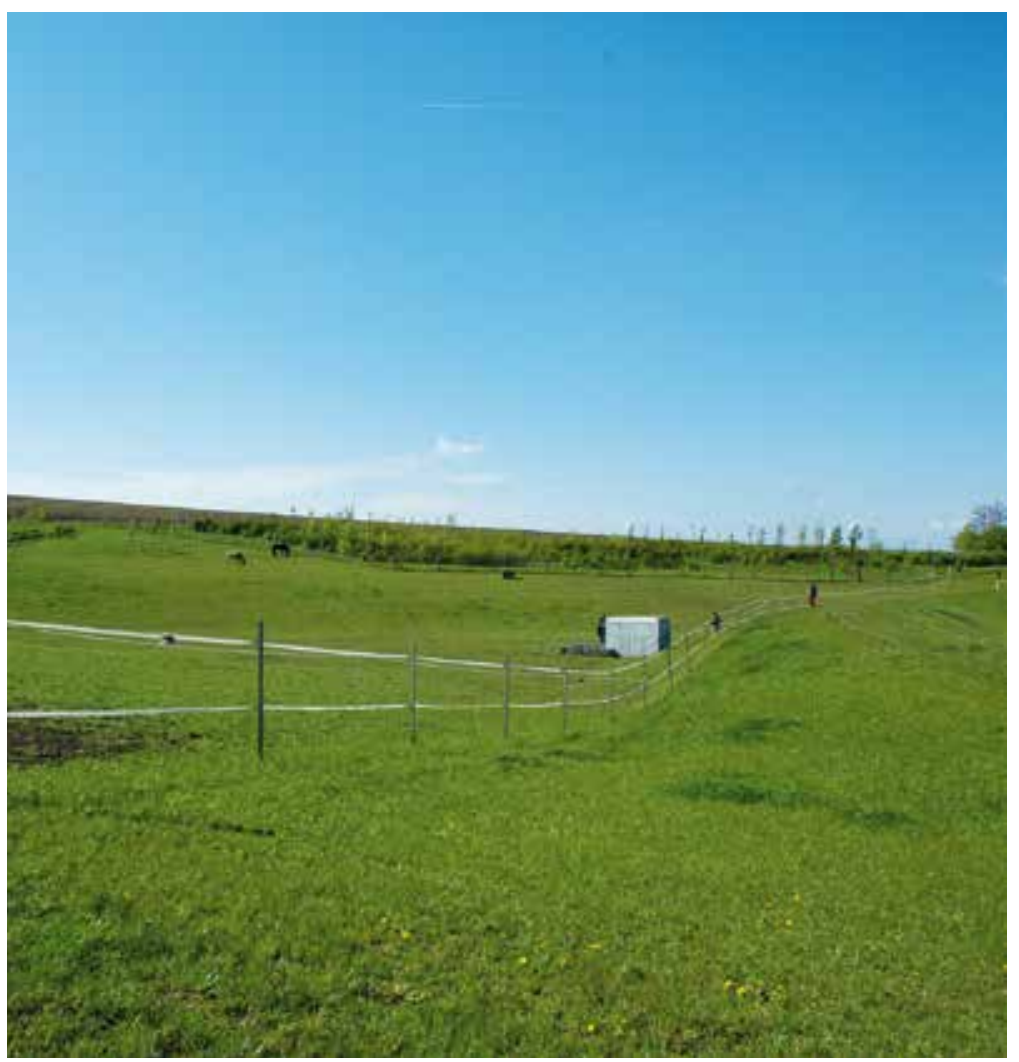

Obr. 3. Suchá nádrž v k. ú. Nenkovice, zátopa využívána k pastvě koní

Fig. 3. Dry retention basin, a floodplain is used to horse pasture, Nenkovice

\section{OPATŘENÍ V LESNÍCH EKOSYSTÉMECH}

Co se týče opatření na lesní půdě nebo obecněji v lesním ekosystému, les jako významný krajinný prvek je značně zranitelný ve vztahu ke klimatické změně, která se projevuje teplotními a srážkovými výkyvy, včetně period sucha. Jde především o velkou setrvačnost zdánlivě se neprojevující žádnou nebo málo presvědčivou reakcí. O to razantnější může být následný kolaps celého systému, např. v návaznosti na dlouhodobá sucha. Z dlouhodobého pohledu by opatření měla směřovat především k postupné revizi systémů lesnické typologie, tvorbě hospodářských souborů a s nimi souvisejících rámcových směrnic hospodaření alespoň v suchem nejvíce ohrožených lokalitách a lokalitách, které mají vysoký potenciál k zadržování vody (lokality s výrazně aktivními vodními bilancemi).

Prvořadým úkolem operativních opatření je udržet srážkovou vodu v lesních porostech. Od prístupu směřujícímu k rychlému odvedení srážkové vody, např. z lesních odvozních cest, skládek dřiví a jiných manipulačních ploch, do recipientů a následně mimo lesní porosty je třeba jednoznačně přejít k př́istupu zadržování a postupnému využívání veškeré vody přicházející do lesních povodí. Opatření jsou přitom poměrně jednoduchá, od opatření v porostech, kdy např. po těžbách je vhodnějši klest vyrovnávat do hromad orientovaných po vrstevnici, na plochách je vhodné ponechávat v rozumné míre přirozené změny mikroreliéfu (např. vývratové jámy), po vlastní technická opatření např. zaústování svodných př́kopů a rigolů do drénů, revitalizace vodních toků, výstavba malých vodních nádrží atp. Vliv lesa a hospodaření v lesích na vodní režim krajiny je v podmínkách ČR natolik zásadní, že hospodaření s vodou v lesích by se do budoucna mělo stát plnohodnotnou součástí lesnických činností.

Pro efektivní zadržení vody $v$ lesích je primárním předpokladem udržení lesa a jeho inventáře v optimální kondici (tzn. v odpovídající dřevinné skladbě v odpovídajících podmínkách, se zdravou lesní půdou, zdravým lesním porostem a optimálním lesním inventářem).

Klíčovými nástroji adaptačních opatření jsou změny dřevinného složení, včetně introdukce nových druhů, zvýšení biodiverzity, snížení doby obmýtí zranitelných dřevin a využívání nepasečných hospodářských způsobů. Obecně nejdůležitějším opatřením je zvyšování adaptačního potenciálu lesů druhovou, genovou a věkovou diverzifikací porostů.

Strategickou záležitost představuje vyhodnocení hydrické a protierozní funkce lesa a jeho zakotvení do rámcového plánování. Vyplývá z toho stanovit na úrovni prírodních lesních oblastí hydrický potenciál lesní půdy včetně vlivu lesních porostů. Na to navazují těžebně-dopravní technologie, které zásadním způsobem ovlivňují hydrický režim lesa.

Všechna výše zmíněná opatření v lesích mají také zpravidla pozitivní vliv na ekologický stav vodních toků. Opatření jsou zaměřena zejména na zadržení srážkové vody v lesních porostech a zajištují infiltrace srážkové vody do hlubších vrstev zvodní, popř. převádí povrchový odtok na odtok podpovrchový. $\checkmark$ prípadě hrazení strží je vhodné přednostně využívat polopropustné hráze. Při průchodu vody zvodní dochází k procesům samočištění a do rríčních systémů vtéká "vyčištěná“ podzemní voda s lepšími fyzikálně-chemickými a chemickými parametry, která podporuje rozvoj vodní bioty a nemění habitatovou strukturu vodních biotopů.

Doporučení vhodných typů opatření v ploše povodí (na zemědělské a lesní půdě) a MVN jsou prehledně znázorněna v tabulce 1.

\section{OPATŘENÍ NA VODNÍCH TOCÍCH A V NIVÁCH}

Prírodě blízké úpravy vodních toků (revitalizace, renaturace) a jejich niv (realizace tůní, mokřadních ploch apod.) jsou souborem dílčích opatření, které v souvislosti s hydrologickým suchem slouží zejména ke třem účelům. Prvním je akumulace vody v podzemní vodě niv, druhým je vytvoření refugií pro vodní biotu a třetím je podpora samočištění.

Revitalizace jsou tak opatřeními, která i při realizaci v omezeném prostoru stávajících koryt toků vytvárí vodním organismům operativní prostor pro únikovou migraci a refugia pro přežití při výskytu sucha. Přínos pro řešení problematiky sucha z pohledu vodohospodářského a ekologického se zvyšuje s komplexností provedení revitalizačních a renaturačních zásahů. $V$ projektech řešených VúV TGM bylo zjištěno, že vliv revitalizace na zlepšení ekologického stavu závisí i na jakosti vod. Dopad na zlepšení fyzikálně-chemických 
Vhodnost $k$ řešení problematiky sucha z hlediska

Typ opatření
Vlivu na fyzikální, fyzikálně-chemické a chemické parametry podporující biologické složky ES/EP

\author{
Vlivu na biotu/ \\ biologické složky \\ určující ES/EP
}

\section{Revitalizace toků v nezastavěných územích:}

\begin{tabular}{|c|c|c|c|}
\hline $\begin{array}{l}\text { komplexní úprava koryta toku v rámci nivy - dlouhý } \\
\text { úsek }\end{array}$ & +++ & +++ & +++ \\
\hline $\begin{array}{l}\text { komplexní úprava koryta toku v rámci nivy - krátký } \\
\text { úsek }\end{array}$ & ++ & ++ & ++ \\
\hline $\begin{array}{l}\text { úprava podélného a příčného profilu, stabilizace } \\
\text { koryta toku - dlouhý úsek }\end{array}$ & ++ & +++ & ++ \\
\hline $\begin{array}{l}\text { úprava podélného a příčného profilu, stabilizace } \\
\text { koryta toku - krátký úsek }\end{array}$ & + & + & + \\
\hline $\begin{array}{l}\text { migrační prostupnost - rekonstrukce příčných prahů } \\
\text { a stupňů - dlouhý úsek }\end{array}$ & + & +++ & ++ \\
\hline $\begin{array}{l}\text { migrační prostupnost - rekonstrukce příčných prahů } \\
\text { a stupňů - krátký úsek }\end{array}$ & + & + & + \\
\hline $\begin{array}{l}\text { změny v rámci koryta - vyšší morfologická členitost - } \\
\text { dlouhý úsek }\end{array}$ & + & ++ & +++ \\
\hline $\begin{array}{l}\text { změny v rámci koryta - vyšší morfologická členitost - } \\
\text { krátký úsek }\end{array}$ & + & + & ++ \\
\hline
\end{tabular}

\section{Revitalizace toků v zastavěných územích:}

komplexní úprava toku v rámci urbanisticky vymezeného prostoru

úprava podélného a príčného profilu, stabilizace koryta toku

migrační prostupnost - rekonstrukce přičných prahů a stupňu

změny v rámci koryta - vyšší morfologická členitost

ohrázování

vegetační doprovod

\section{Opatření v údolních nivách toků:}

umožnění rozlivů, změna využívání inundace

$+++$

nivní a odstavená ramena

tůně a vodní plochy v parametrech bývalých koryt toku

obnova potenciálně přirozené nivní vegetace

\begin{tabular}{lll}
+ & ++ & + \\
+ & + & + \\
+ & + & + \\
\hline 0 & 0 & -
\end{tabular}

$+$

$++$

$+$ 
Vhodnost $k$ řešení problematiky sucha z hlediska

Typ opatření

Vlivu na fyzikální,
fyzikálně-chemické
a chemické parametry
podporující biologické
složky ES/EP

\section{Vlivu na biotu/ \\ biologické složky určující ES/EP}

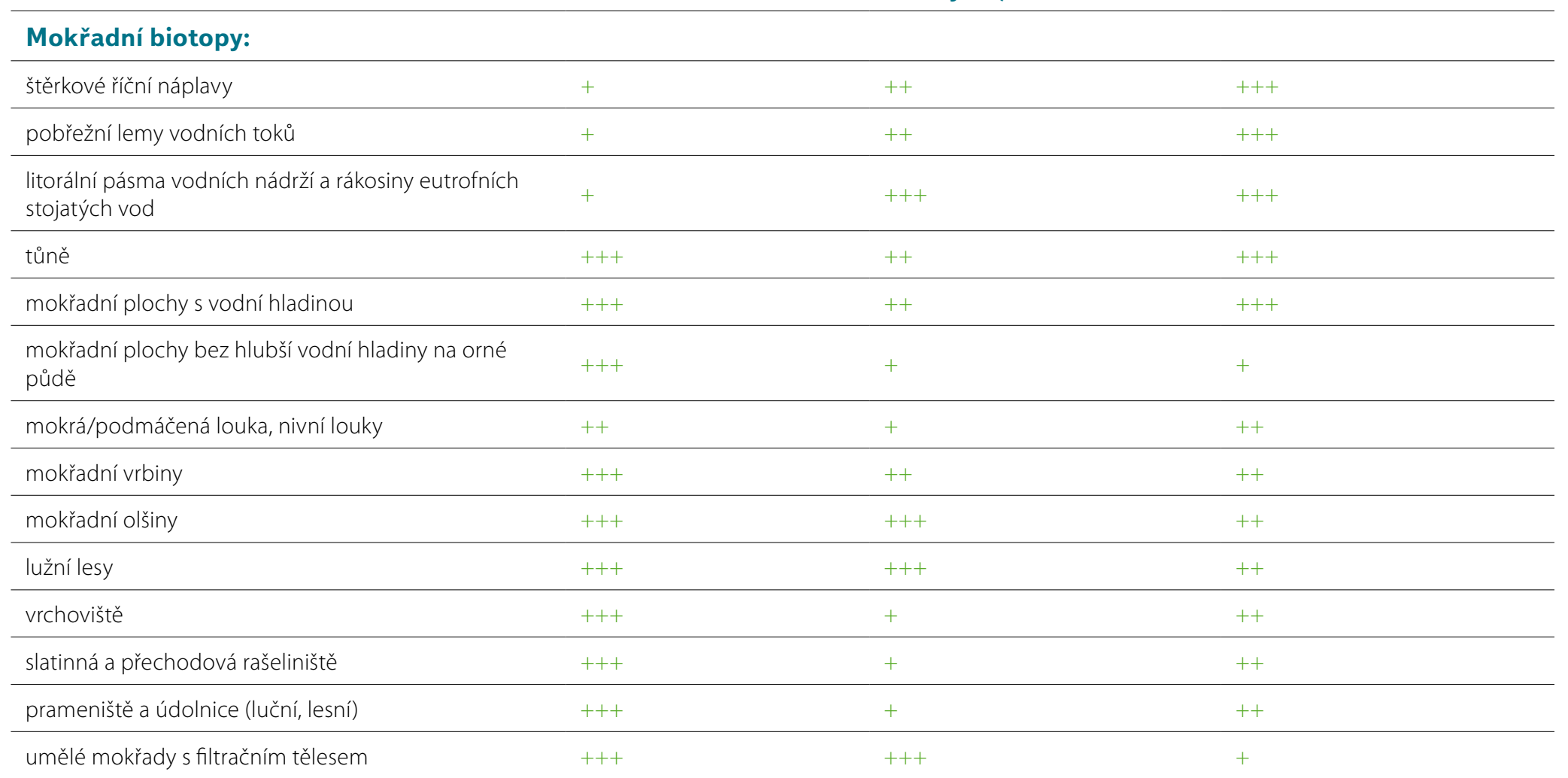

Legenda: -, $0,+,++,+++-$ míra vhodnosti opatření od nevhodného po nejvhodnější

parametrů vodního prostředí se zvyšuje s délkou revitalizačních úprav. Např. při rešení projektu ProFor - Výzkum procesů samočištění drobných, silně degradovaných toků v oblasti Weinviertel a jižní Moravy: Vývoj metodiky pro trvale udržitelná opatření ke zlepšení jakosti vod v letech 2009-2011 bylo prokázáno, že pro odstranění určitého množství živin ve vodě je u malého vodního toku v zemědělsky intenzivně využívané krajině jižní Moravy s úpravou členitosti dna a svahů v rámci stávajícího regulovaného koryta potřeba mnohem kratší délka toku, než v případě regulovaného, naprímeného úseku s jednotvárnou kynetou. Podobné úpravy toků, které nezasahují př́liš do majetkoprávních poměrů, mohou pomoci zlepšit situaci v miŕe znečištění navazujících páteřních toků, pomoci k dočištění vypouštěných čištěných odpadních vod na kratším úseku (prínos v obdobích s nízkou vodností toků). Opatření v údolních nivách, která zvýší jejich diverzitu a rozsah, zvýší i jejich potenciál zásaku vod při rozlivech. Obecně realizace všech typů mokřadních biotopů v krajině podporuje zadržení vody, výpar v místě, rozšiřuje plochy ohrožených a cenných biotopů.
Mokřady a břehové zóny podél vodních toků plní tyto hydrologické a ekosystémové služby a funkce [6]:

- zadržení vody během mokrých období a protipovodňová ochrana,

- rezervoár vody během suchých období,

- zadržení sedimentů a přidružených polutantů (jejich uložení),

- zadržení nutrientů (absorpce, denitrifikace) a polutantů na jejich cestě do řičního systému,

— zajištění přirozeného prostředí pro rybářství,

— zachování biologické diverzity.

Mokřady patří mezi nejúčinnější prvky pro obnovu krátkého vodního cyklu v krajině. Živiny a látky unášené vodou se zde využívají a usazují, neodcházejí z povodí, recyklují se. Mají vyrovnávací funkci pro průtok vody a filtrační funkci pro sedimenty a rozpuštěné nutrienty a polutanty. Pomáhají zmírňovat dopady povodní, zlepšují kvalitu vody ve vodních tocích, zmírňují dopady sucha a redukují proces eroze. Historické porozumění vzniku mokřadů a jejich dynamice je základním předpokladem pro efektivní opatření pro jejich management, ochranu a obnovu. $V$ současnosti končí životnost některých drenáží na zemědělské půdě a taková území se navrací do zamokřeného stavu. Informace o lokalizaci těchto ploch mohou být součástí podkladů pro rozhodování o zachování spontánně vznikajících mokřadů nebo pro realizaci nových. 


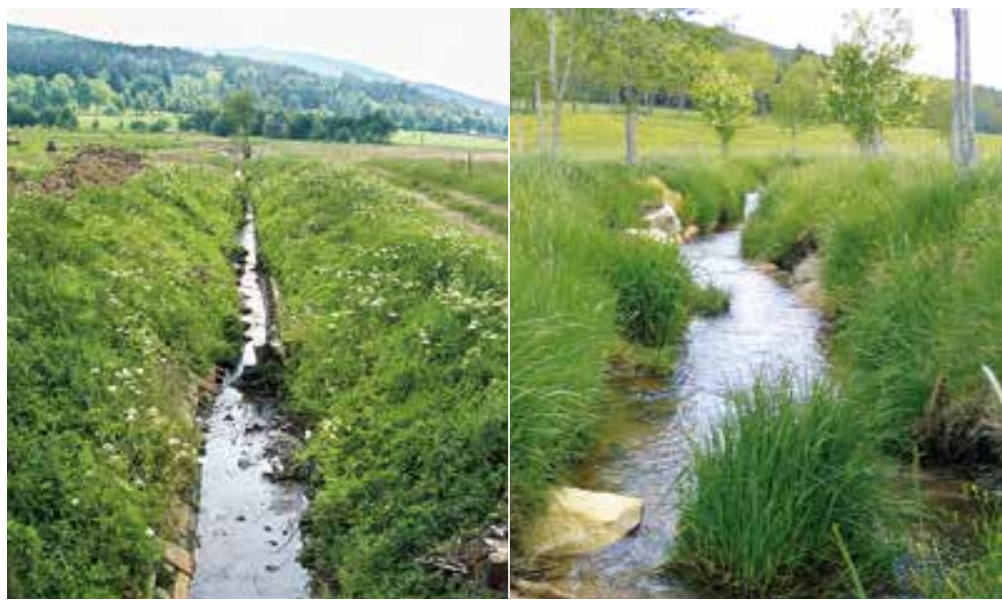

Obr. 4. Koryto potoka Borová před revitalizací (vlevo), revitalizované koryto v roce 2006 (vpravo)

Fig. 4. Borová stream before revitalization (on the left), revitalized riverbed in 2006 (on the right)

Klíčovými mokřadními prvky v krajině jsou prameniště a na ně navazující plochy a údolnice. Tyto mokřady by měly být chráněny, vyjmuty z obhospodařování pozemků a zahrnuty do realizací komplexních opatření (protierozních, protipovodňových, revitalizačních atd.). Mokřadní biotopy jsou součástí niv vodních toků a při plánování revitalizačních opatření by měly být jejich součástí. Při návrhu konkrétních mokřadních prvků je třeba vždy zvážit jejich následný vývoj, možnost zanášení, zarůstání a prípadně plánovat cílový stav prvků.

Doporučení vhodných typů opatření na vodních tocích a v nivách jsou prèhledně znázorněna v tabulce 2 .

\section{Hodnocení účinnosti a vhodnosti navrhovaných typů opatření}

V pilotním povodí Husího potoka bylo provedeno zpracování komplexního návrhu opatření s cílem zvýšení retence vody v povodí. Základem byla volba vhodných morfologických profilů pro následnou realizaci retenčních malých vodních nádrží doplněná návrhem ochranných, organizačních a biotechnických opatření v ploše povodí. Návrhy následně prošly vyhodnocením jejich

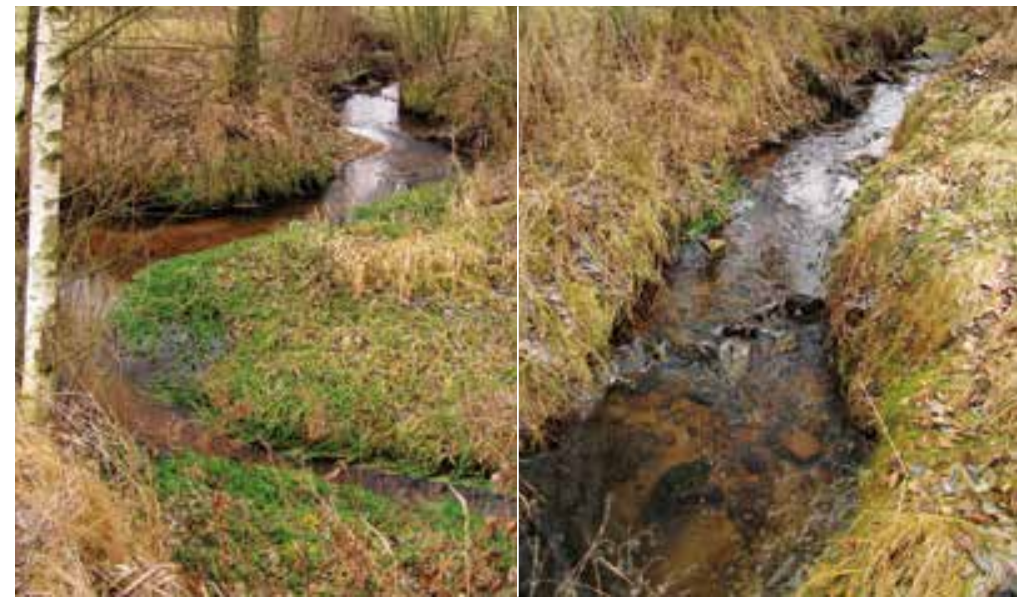

Obr. 5. Revitalizované koryto potoka Borová v roce 2016

Fig. 5. Revitalized riverbed of Borová stream in 2016

vlivu na odtok z povodí a retenci vody v krajině za pomocí hydrologického modelování srážko-odtokovým modelem v programu HEC-HMS [7].

Z výsledků (tabulka 3) vyplývá, že i aplikací organizačních a agrotechnických opatření na orné půdě, tedy tzv. nižších opatření, které lze aplikovat bez povolení vodoprávními úřady či složitějších dokumentací, Ize zvýšit retenci vody $\checkmark$ krajině o několik procent (téměř $9 \%$ v modelovaném prípadě). S tzv. vyššími opatřeními (TTP, biotechnická opatření, vodní nádrže) zvýšení retence vody v povodí prudce stoupá (až 42\% v modelovaném prípadě).

Doporučení jednotlivých typů opatření v ploše povodí (na zemědělské i lesní půdě), typů malých vodních nádrží i opatření na tocích vedoucích ke zvýšení retence vody v krajině jsou shrnuta v tabulkách 1 a 2, včetně vhodnosti jejich použití z hlediska vodohospodářského vlivu na biologické složky určující ekologický stav vodních útvarů a vlivu na fyzikální, fyzikálně-chemické a chemické parametry podporující biologické složky ekologického stavu. V prílohách P1-P7 zprávy [2] jsou podrobněji uvedeny výhody a nevýhody (klady a zápory) jednotlivých typů opatření.

Pro exaktnější hodnocení vlivu opatření na ekologický stav vodních útvarů je doporučeno zavést dlouhodobou účelovou podporu monitoringu kvality vod a bioty před a po realizaci prírodě blízkých opatření v ploše povodí

Tabulka 3. Vliv navržených opatřenína zadržení vody v povodí

Table 3. Effect of proposed measures on water retention in the catchment area

\begin{tabular}{|c|c|c|c|}
\hline Typ opatření & Kulminační průtok [m³/s] & Objem odtoku $\left[\mathrm{m}^{3}\right]$ & Zadržený objem v krajině $\left[\mathrm{m}^{3}\right]$ \\
\hline bez opatření & 7,6 & 802000 & - \\
\hline PEO & 6,9 & 730300 & 71700 \\
\hline TTP & 6,5 & 683500 & 118500 \\
\hline RN & 5,3 & 520400 & 281600 \\
\hline RN + PEO & 4,9 & 484500 & 317500 \\
\hline RN + TTP & 4,7 & 463400 & 338600 \\
\hline
\end{tabular}

(Vysvětlivky: PEO - protierozní opatření (organizační a agrotechnická), TTP - trvalý travní porost, RN - retenční nádrž) 
a na tocích. Průzkumy by měly být komplexní a opakované v určitém časovém kroku. Za účelem snižování nejistot v hydrologickém modelování (zejména nejistoty vstupních dat) je vhodné doplňovat měřící systémy (srážkoměry, hladinoměry) i do malých povodí.

\section{ZÁVĚR}

Prírodě blízká opatření v ploše povodí i na vodních tocích jsou opatření, která spolu úzce souvisí. Je nutné si uvědomit, že tato opatření přispívají nejen ke snížení povodňového nebezpečí a snížení ztráty půdy smyvem, ale podporují i zasakování a akumulaci vody v krajině a zpomalují povrchový odtok. To jsou hlavní aspekty pro zvládání problematiky sucha - podpora infiltrace a prodloužení doby vsaku i zpomalení povrchového odtoku.

Využití jednotlivých typů opatření by mělo být hierarchicky uspořádáno s ohledem na aktuální stav posuzovaného území. Přednost je nutno dávat měkkým typům opatření s reverzibilním charakterem (opatření na zemědělské a lesní půdě, budování mokřadů, tj. zelená opatření). Budování nádrží, jejich obnova nebo prípadně převody vody mezi povodími (technická opatření) by měly být brány $v$ potaz jako poslední článek komplexního systému řešení. U technických opatření je potřebné upřednostnit optimalizované využití stávajících kapacit před budováním nových staveb.

Optimálním řešením pro krajinu jako celek je komplexní př́stup k řešení problematiky sucha, tzn. navrhovat kombinaci vhodně se doplňujících všech typů opatření.

\section{Poděkování}

Př́spěvek vznikl v rámci úkolư řešených pro Ministerstvo životního prostředí České republiky.

\section{Literatura}

[1] ČSN 75 2410. Malé vodní nádrže, Praha, 2011.

[2] DZURÁKOVÁ, M. a kol. Činnosti k podpoře výkonu státní správy v problematice SUCHO v roce 2016 - úkol 3702. Potenciál aplikace prírodě blízkých opatření pro zadržení vody v krajině a zlepšení ekologického stavu vodních útvarů. Zpráva, Brno: VúV, 2016, 224 s.

[3] PAVELKOVÁ CHMELOVÁ, R., FRAJER, J., NETOPIL, P. a kol. Současný stav historických rybníků na území České republiky. Specializovaná mapa s odborným obsahem. Certifikace MZe ČR č. j. 83277/2013 MZE-14130, 31. 10. 2013

[4] DLABAL, J., PICEK, J., DZURÁKOVÁ, M., ROZKOŠNÝ, M., PAVELKOVÁ, R., DAVID, V. Hodnocení území na bývalých rybničních soustavách (vodních plochách) s cílem posílení udržitelného hospodaření s vodními a půdními zdroji v ČR - interaktivní aplikace [on-line], 2015, 30. 1. 2014

[5] DAVID, V., DAVIDOVÁ, T., VRÁNA, K., KOUDELKA, P., PAVELKOVÁ, R. a ROZKOŠNÝ, M. Hodnocení ploch zaniklých rybníků z hlediska optimalizace jejich využití. Certifikovaná metodika pro praxi. Certifikace MZe ČR č.j. 19004/2015-MZE-15100. Praha: ČVUT, 2015, 57 s.

[6] HATTERMANN, F.F. KRYSANOVA, V., and HESSE, C. Modelling wetland processes in regional applications. Hydrological Science Journal, vol. 53, No. 5, 2008, p. 1001-1012.

[7] HEC - Hydrologic Engineering Center. US Army Corps of Engineers [online], 2010 [cit. 2010-06-13] Dostupné z: http://www.hec.usace.army.mil/

\section{Autoři}

Ing. Miriam Dzuráková

凶iriam.dzurakova@vuv.cz

Ing. Kamila Zárubová

凶kamila.zarubova@vuv.cz
Ing. Jana Uhrová, Ph.D.1

凶jana.uhrova@vuv.cz

Ing. Miloš Rozkošný, Ph.D.'

凶milos.rozkosny@vuv.cz

Ing. Lukáš Smelík, Ph.D.'

凶lukas.smelik@vuv.cz

RNDr. Denisa Němejcová

$\triangle$ denisa.nemejcova@vuv.cz

doc. RNDr. Světlana Zahrádková, Ph.D. ${ }^{1}$

凶svetlana.zahradkova@vuv.cz

Mgr. Pavla Štěpánková, Ph.D.

凶pavla.stepankova@vuv.cz

Dr. Ing. Jaromír Macků2

凶macku@brno.uhul.cz

'Výzkumný ústav vodohospodářský T. G. Masaryka, v. v. i.

2Ústav pro hospodářskou úpravu lesů Brandýs nad Labem

\section{POTENTIAL OF THE NATURE-FRIENDLY MEASURES APPLICATION FOR WATER RETENTION IN THE LANDSCAPE AND IMPROVEMENT OF THE ECOLOGICAL STATUS OF WATER BODIES}

\section{DZURAKOVA, M.'; ZARUBOVA, K.'; UHROVA, J.'; ROZKOSNY, M.'; SMELIK, L.'; NEMEJCOVA, D.'; ZAHRADKOVA, S.'; STEPANKOVA, P.'; MACKU, J. ${ }^{2}$}

${ }^{1}$ TGM Water Research Institute, p. r. i.

${ }^{2}$ The Forest Management Institute

Keywords: drought - water retention - nature-friendly measures measures in the catchment area - small water reservoirs measures on watercourses - biological quality elements

An analysis and assessment of the nature-friendly measures potential for water retention in the landscape were carried out as a part of the work on the concept of protection against drought impacts in the Czech Republic. Selected types of area measures (on agricultural and forest land), small water reservoirs and measures on watercourses were assessed, including their potential impact on the biological elements of the ecological status. The recommendations of appropriate types of measures to increase the water retention in the landscape are the result of this assessment. These recommended types of measures will contribute to the improvement of the ecological status of the water bodies or at least not impair it. The effectiveness of the proposed measures was verified in the Husí brook pilot catchment by modeling in the HEC-HMS software. 